\title{
414. 写実体ファントムを用いた脳表面の熱中性子束分布測定の再現性
}

\author{
山本 和喜 $1, *$, 熊田 博明 1 , 山本 哲哉 $2, \uparrow$, 松村 明 ${ }^{3}$ \\ Reproducibility of Thermal Neutron Flux Distribution on Patient's Brain Surface with a Realistic Phantom
}

Kazuyoshi YAMAMOTO, Hiroaki KUMADA, Tetsuya YAMAMOTO and Akira MATSUMURA

\begin{abstract}
To investigate the reproducibility of experimental approach for dose evaluation using a realistic phantom that faithfully reproduced the shape of a head, we considered the manufacture of a patient's realistic phantom and the reappearance of actual medical irradiation conditions. We selected the rapid prototyping technique to produce the realistic phantom from the Computed Tomography (CT) imaging. This phantom was irradiated under the same clinical irradiation condition of this patient, and the thermal neutron distribution on the brain surface was measured in detail. Several subjects on material and data conversion in the production of realistic phantom were mentioned. As a result of reproducing medical irradiation using the realistic phantom, the maximum thermal neutron flux became a value about $22 \%$ lower than the surface of the actual brain. If the problems pointed out in this paper are solved, it may also be expected that it would become possible to check computational dosimetry system.
\end{abstract}

KEYWORDS: boron neutron capture therapy, neutron dosimetry, rapid prototyping, phantom experiment, treatment planning system, research reactor

\section{I. 緒 言}

放射線医療においては，病巣に治療必要線量を投与し， 正常な組織には可能な限り被曝線量を低減することが必要 となるため, 事前にコンピュータ支援による治療計画シス テムを用いて照射計画を組み，その計画に忠実な照射を行 うことが重要となる。一方, 生体内での詳細な線量モニタ リングがほとんど不可能なため，人体に対する放射線の影 響を定量的かつ客観的に評価することを目的に，人体組織 および形状特性を再現したファントムが用いられており， 計算シミュレーションの検証およびビームの性能確認に利 用されている。中性子線を用いるホウ素中性子捕捉療法 (BNCT : Boron Neutron Capture Therapy)においても， 中性子散乱能を等価とするために办素密度を合わせた材料 で幾何学形状のファントムが作られて扣り, 線量分布測 定, 細胞生存率測定などに用いられている。最近の臨床試 験側の関心は，医療照射後定期的に撮影しているMRI (Magnetic Resonance Imaging) 等加ら判断する被照射部 位の健全性1,2)について, 治療効果と各線量値とを比較 し，耐用線量および治療線量を決定していくことにある。 幾何学形状のファントムでは臨休上の要求を満たするので はなく，中性子ビーム経路に存在する吸収散乱の大きい障

1 日本原子力研究所 (Japan At. Energy Res. Inst.)

2 茨城県立中央病院 (Ibaraki Prefectual Central Hospital)

3 筑波大学 (Univ. of Tsukuba)

（2003年 11月 6 日 受理；2004年 1 月26日 查読通過）

* 著者連絡先 : Tel. 029-282-5746, Fax. 029-284-3870,

E-mail: yamamoto@popsvr.tokai.jaeri.go.jp

†現在, 筑波大学(Univ. of Tsukuba)
害物の影響, 境界面での中性子の挙動などを忠実に再現で きる線量評価方法が必要とされている。これらを補うた め，我々は計算シミュレーションによる線量評価ができる 線量評価システム (JCDS : JAERI Computational Dosimetry System) ${ }^{3,4)}$ を開発しており，これと並行して忠実に 形状を再現した写実体ファントムを用いた実験的手法によ る線量評価について検討している。

人の頭部の形状に忠実な写実体ファントム（以下，頭部 モデルファントムと呼ぶ)の製作を可能とする技術として， CT (Computed Tomography) 等の断層写真から忠実な 立体造形が可能な光造形技術 (Rapid Prototyping

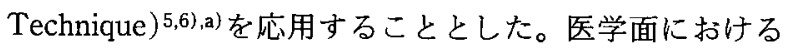
光造形技術は，MRIやCT スキャンで得られた断層デー タをもとに患部の標本(レプリカ)の作成にすでに応用され て扔り，腫瘍や骨の異常，その他の病気の確実な診断方法 や難しい外科手術の手順検討に利用されている。放射線治 療の分野に限ると個人の線量分布の測定を目的とした写実 体ファントム製作の報告はなく，眼窩の小線源治療の線量 分布を計画どおり実施するためのバイオモデルの製作 や7)，陽子線治療のフィルタの製作8) が報告されているに すぎない。

以上の観点より, 本研究では, 日本原子力研究所の

\footnotetext{
a) 光造形技術は, 3 次元 CAD (Computer-Aided Design)データか ら 3 次元モデルを迅速に得るための新しい技術であり，半導体 の生産技術, 印刷技術, $\mathrm{CAD}$ 技術の 3 分野の統合から生まれ た技術である。光造形の造形手順は，应置制御された紫外線 レーザー・ビームを液状の光硬化性樹脂に照射し，平面的に硬 化させ，その薄膜を皘層させることにより目的の 3 次元立体物 を生成するというむのである。
} 
JRR-4 (Japan Research Reactor No. 4)で, 治療を受けた 患者 1 名の頭部を対象に光造形技術を応用して，頭部乇 デルファントムを製作することにより，製作技術における 課題抢よび製作䛊差を確認するとともに，当該患者の医療 照射条件を同ファントムで再現し，脳表面線量分布の測定 の可能性について検討を行った。

\section{II. 実 験 方 法}

\section{1. 頭部モデルファントムの製作}

頭部モデルファントムの設計方針は，該当する患者の CT 画像 (5 mmごとのスライス画像 $\times 40$ 枚)をもとに, 光 造形技術の手順に沿って立体造形するものとし，内部に水 を満たすことのできる構造とした。内部に水を満たす構造 は検出器を挿入し物理線量を評価することはもちろんのこ と, 細胞培養容器を入れて生物学的効果の測定 ${ }^{9)} に も$ 応用 可能であるからである。中性子線量測定用のファントム製 作において重要なことは, 中性子線量の分布を決定する水 素密度を，いかに組織等価にするかということである。フ アントム材料として使用する光造形樹脂 TSR-810 (帝人 製機秼)の主成分であるエポキシアクリレートの水素の密 度は $0.0796 \mathrm{~g} / \mathrm{cm}^{3}$ であり, 脳組織(水素の密度 : 0.1113 $\mathrm{g} / \mathrm{cm}^{3}$ ) や通常ファントム材として用いられる水(水素の密 度 : $\left.0.1111 \mathrm{~g} / \mathrm{cm}^{3}\right)$ と比較すると $30 \%$ 程度小さい。光造形 技術を用いると，形状を正確に再現できる反面，水素密度 について正確に模擬することはできないという製作上の課 題が挙げられる。

本研究ではファントム形状を優先し，水素密度の違いに ついては，本ファントムを薄肉構造 (肉厚 $3 \mathrm{~mm}$ )にするこ とで対処することとした。採用した光造形樹脂 TSR-810 は脂環族エポキシ化合物に，嵩高い基を分子内に有する多 官能アクリレート・オリゴマーやモノマーを加え，アリー ルスルホニウム塩系光カチオン重合開始剤, ラジカル重合 開始剤および各種添加剂を含有させたものである。TSR810 の主な特徵として，

(1) 皮膚に対して低刺激性

（2）造形性に優れた硬化深度

（3）ほぼ ABS (Acrylonitrile Butadiene Styrene) 樹脂の 物性之同程度(酎衝撃性を除く)

（4）造形物の後加工性が良好，不ジ立てが可能 が挙げられる。

今回のファントム製作に係る処理工程を説明する。一般

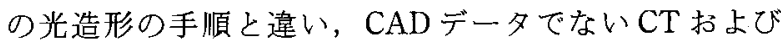
MRIの医療用データを基に，軟組織の輪郭を抽出された 点群データから 3 次元デザインソフトを用いて, STL (Stereolithography)フォーマット5)へ変換する前処理を必 要とする。まず，医療データから解読された各 CT のスラ イス画像上で骨，頭皮を取り除き(術野の再現)，画像を 2

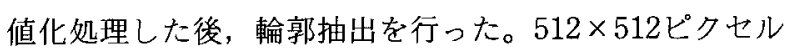
で撮影されたCT データから抽出される輪郭の点群データ
が得られる。SURFACER(Imageware 社)を用いて, 点群 データを面データへ変換し，さらにSTL形式で保存し， 次の造形用ソフトMagics RP へ受け渡した。Magics RP はベルギーの Materialise 社の製品であり，STLファイル を読み込み, 光造形用に修正・編集できるソフトウェアで ある。内部に水を蓄えることのできる中空・薄肉 (肉厚 : $3 \mathrm{~mm}$ ) 構造とするため，Magics RPを用いて面データへ の肉付け処理とフランジの追加を行った。

造形装置は帝人製機秼の SOLIFORM-500B を用いて行 った。造形装置へ入力されるまでの処理工程はすべてコン ピュータ上で作業を進めることができる。さらに，積層回 数を少なくすれば製作時間が短縮できるため, 本ファント ムは 2 分割して同時造形を行い, 各部品をセメダイン。 ハイスーパ(E335G30)を用いて接着することとした。完 成体を完全に硬化させるため，さらに全体に紫外線で照射 を行った。ファントム内部の防水処理として表面にアクリ ルニトリルゴム系接着剤であるハイボン2047(日立化成ポ リマー侏)を塗布した。乾燥したアクリルニトリルの水素 密度は $0.0459 \mathrm{~g} / \mathrm{cm}^{3}$, 厚さは約 $20 \mu \mathrm{m}$ である。完成した 頭部モデルファントムを Fig. 1 に示す。完成体の寸法精 度を評価するために，高さ，幅，奥行き，フランジの外径 等をノギスにて測定を行った。

\section{JRR-4 中性子ビーム設備}

JRR-4 中性子ビーム設備は，Fig. 2 に示すように，重 水タンク，ビスマスブロック，カドミウムシャッタ等によ り構成されており, 重水タンクの重水層の厚さを変えるこ とで中性子スペクトルを段階的に調整する機能を備えてい る。また，カドミウムシャッタは，熱中性子をカットする よう設計され抢り，重水タンクと組み合わせることによ り，熱中性子束と熱外中性子束が混在する熱中性子モード I，中性子スペクトルを最も軟化させた熱中性子モード II，熱中性子束をカットした熱外中性子モードの代表的な 3つのモードが医療照射用に設定されている。

\section{3. 照射および測定方法}

頭部モデルファントムの中性子照射実験を行うため，医 療照射時と同じ照射条件 (照射位置, コリメータ径, ビ一 ムモードなど)にあわせて照射を行う。熱中性子束分布の 測定は金箔 $(5 \mathrm{~mm} \times 5 \mathrm{~mm}$, 厚さ $0.01 \mathrm{~mm})$ を用いて行 う。金箔を用いた䇴放射化法による熱中性子束測定法は， 裸で照射した金箔の放射化量からカドミウム板 $(0.5 \mathrm{~mm}$ 厚)をかぶせた金箔の放射化量を差し引き，正味の熱中性 子による放射化量を求め, 熱中性子束を計算するものであ る。裸の金箔を頭部モデルファントムの脳表面に取り付け た時点の写真と裸の金箔31枚の配置を Fig. 3 に示す。

通常，医療照射ではコリメータに加え，患部の照射野の 形状に合わせて ${ }^{6} \mathrm{LiF}$ 入り熱可塑性プラスチックを用いて 熱中性子を遮へいしている。この中性子遮へいプラスチッ 


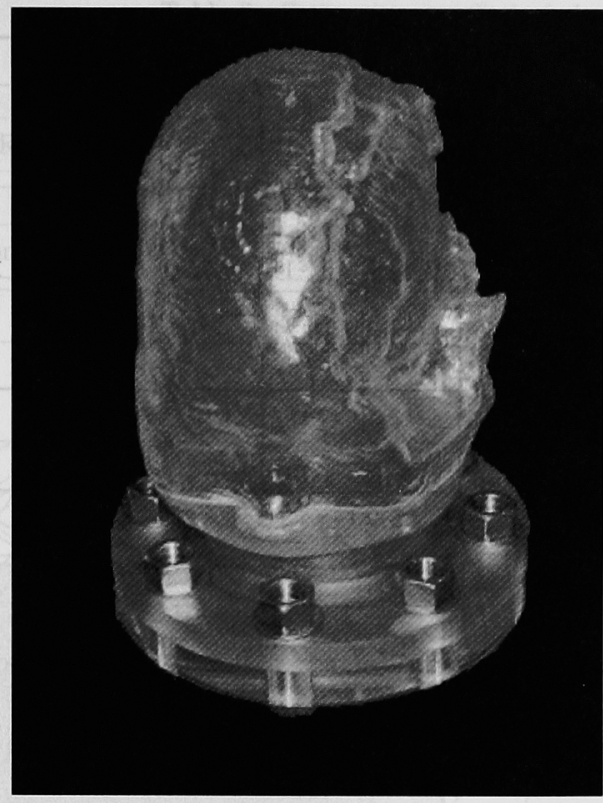

(a)

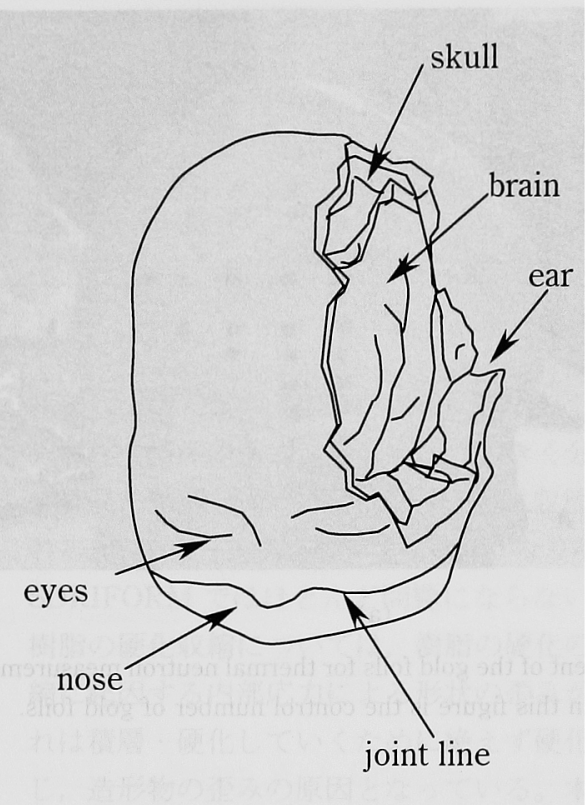

(b)

Fig. 1 The photograph of the completed head model phantom; (a) Photograph, (b) Sketch

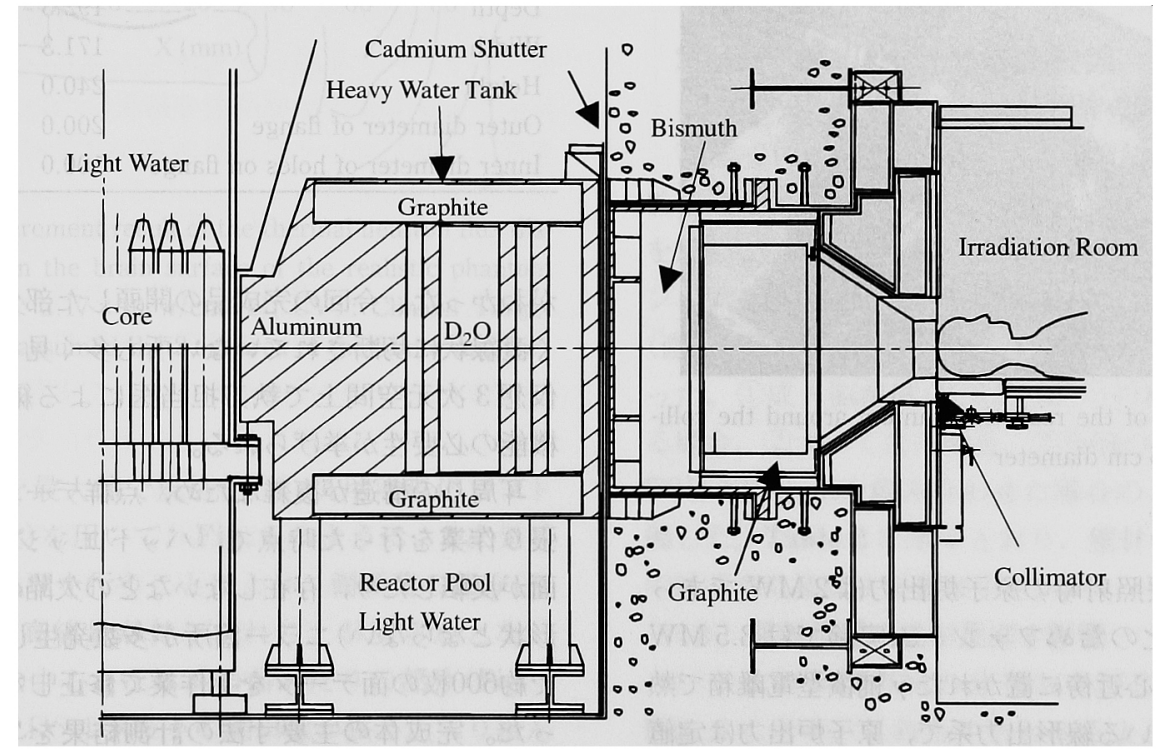

Fig. 2 JRR-4 Medical Irradiation Facility

クのことをLiヘルメットと呼んでおり，本患者の医療照 射時に使用したむのを頭部モデルファントムにそのまま装 着させた。また，医㞠照射では，腫瘍を摘出した後のキャ ビティ部分にゴム風船等を挿入し，線量分布の改善を図っ ている10)。これをボイドと呼んでおり，熱中性子 BNCT では欠かせない照射技術の一つである。これを模擬するた めに，医療照射当時の写真および資料を参考に，ボイドは 発泡スチロールで形状を再現し，ファントム内面に装着さ 机た。

医療照射時の照射位置を再現できるよう，患者セッティ
ングシステム11)の手法を用いて頭部モデルファントムを 配置した(Fig. 4 参照)。医療照射時の位置の測定点は, (1)鼻根部, (2)右外眼角, (3)右外耳孔, (4)鼻背最下点であっ たので，ファントムも同じ測定点を測定した。位置決めに ついて，裸の金筞照射時と医療照射時の位置データを比較 すると重心間の距離(上記 4 点の重心同士の距離)で比較 した結果, $4.1 \mathrm{~mm}$ であった。

照射条件は JRR-4 医療照射設備の熱中性子モード I（重 水タンクの重水厚さ $12 \mathrm{~cm}$ )を用いて，裸の金箔について 30分間，カドミウム板で覆われた金䇴について60分間の 


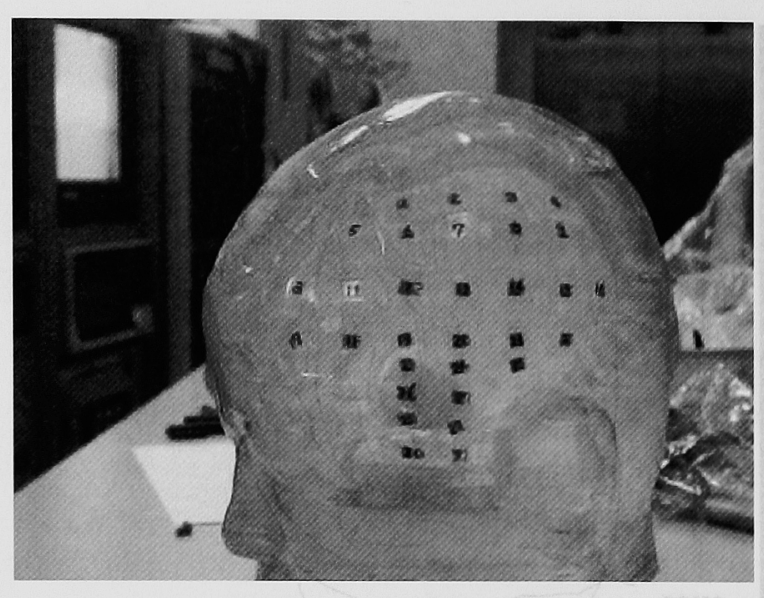

(a)

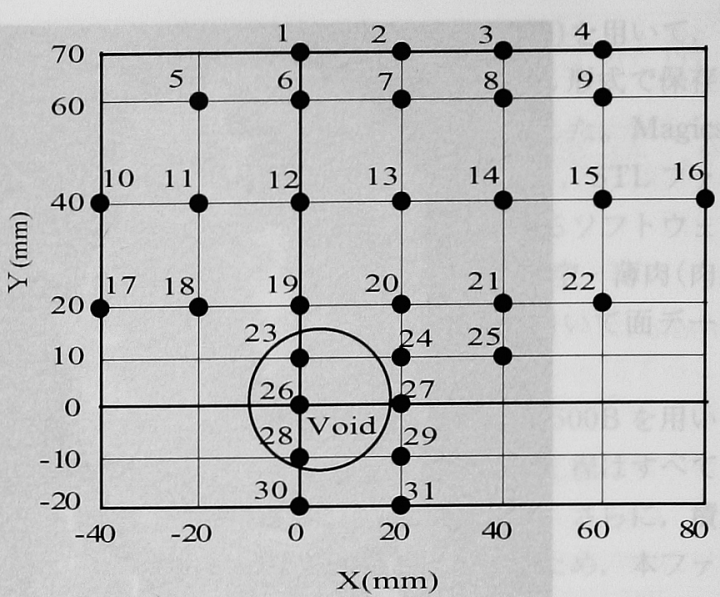

(b)

Fig. 3 Attachment of the gold foils for thermal neutron measurement on brain surface of the realistic phantom; (a) Photograph, (b) The number in this figure is the control number of gold foils.

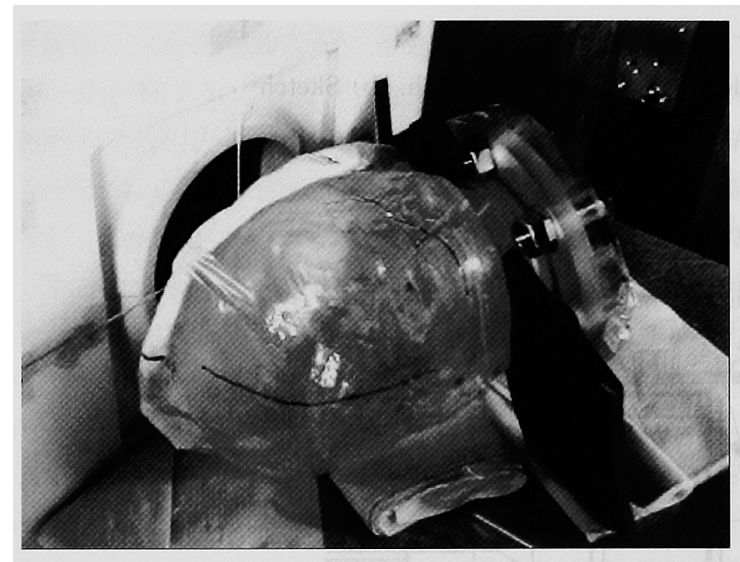

Fig. 4 Arrangement of the realistic phantom around the collimator with $15 \mathrm{~cm}$ diameter

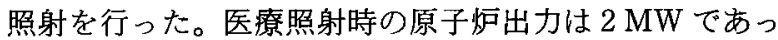
たが，測定の効率化のためファントム実験では $3.5 \mathrm{MW}$ で照射を行った。炬心近傍に置かれた $\gamma$ 補償型電離箱で熱 中性子をモニタしている線形出力系で，原子炉出力は定値 制御されており，中性子ビーム設備のビーム強度と比例し ている。照射された金䈃の放射能測定は，JRR-4にある オートサンプルチェンジャ付 $\beta-\gamma$ 同時測定装置 ${ }^{12)}$ を用い て行った。本ファントム照射から得られた熱中性子束と当 該患者の医療照射時に得られた熱中性子束とを比較した。

\section{III. 結 果}

\section{1. 頭部モデルファントムの製作における技術的課} 題

術野を再現する場合，各スライス画像上で骨，頭皮の切 開筒所を見極めなくてはならないが，画像だけでは判断で きない部分も多く，執刀を担当した医師にスライス画像上 に線を描いてもらうなど，医学的な知識を必要とすること
Table 1 The result of size inspection of a head model phantom (unit: $\mathrm{mm}$ )

\begin{tabular}{lccc}
\hline \multicolumn{1}{c}{ Point } & Design & Measure & Error \\
\hline Depth & 192.3 & 192.4 & +0.1 \\
Width & 171.3 & 171.4 & +0.1 \\
Height & 240.0 & 240.2 & +0.2 \\
Outer diameter of flange & 200.0 & 199.8 & -0.2 \\
Inner diameter of holes on flange & 100.0 & 99.8 & -0.2 \\
\hline
\end{tabular}

がわかった。今回の完成品の開頭した部分を見ると，うま く直線状に切断されていない所む多く見られ，課題として 仮想 3 次元空間上で執刀担当医による編集を可能とする 機能の必要性が挙げられる。

耳周りの構造が複雑なため, 点群データを読み込んで面 張り作業を行った時点で, バッドエッシと呼ばれる（三角 面が反転したり，存在しないなどの欠陷のためスムーズな 形状とならない)エラ一箇所が多数発生し, Magics RP 上 で約600枚の面データを手作業で修正しなければならなか った。完成体の主要寸法の計測結果を Table 1 に示す。 写実体ファントムの寸法誤差は最大 $0.2 \mathrm{~mm}$ であった。

\section{2. 熱中性子束分布測定}

頭部モデルファントムの脳表面で測定された熱中性子束

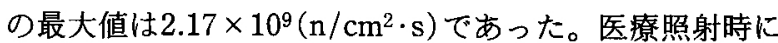
脳に刺し込んだ金線の脳表面上の位置における熱中性子束 の值と比較して，本ファントム実験で得られた值 (1.81× $10^{9} \mathrm{n} / \mathrm{cm}^{2} \cdot \mathrm{s}$ ) は約 $22 \%$ 低い值を示していることがわかった。

本患者の医㞠照射時の線量分布は, 脳表面の熱中性子束 分布は十字状に置かれた 2 本の金線と脳に挿入された 1 本の金線を用いて測定されているだけで，詳細な分布がわ からなかった。そこで, 頭部モデルファントムの脳表面上 の 2 次元分布を観察するため，金䇴の放射化法から得ら 
Table 2 Estimation on effect of phantom materials with MCNP-4C code

\begin{tabular}{lcccc}
\hline \multicolumn{1}{c}{ Case } & $\begin{array}{c}\text { Phantom wall material } \\
\text { with 3 mm thickness }\end{array}$ & Phantom material & $\begin{array}{c}\text { Thermal neutron flux } \\
\text { on the phantom surface }\end{array}$ & Error for the brain \\
\hline Adult brain (ICRU-46) & Brain tissue & Brain tissue & $4.173 \times 10^{9}$ & $+0.5 \%$ \\
\hline Water & Water & Water & $4.195 \times 10^{9}$ & $+0.2 \%$ \\
\hline Realistic phantom & TSR-810 & Water & $4.180 \times 10^{9}$ & . \\
\hline
\end{tabular}

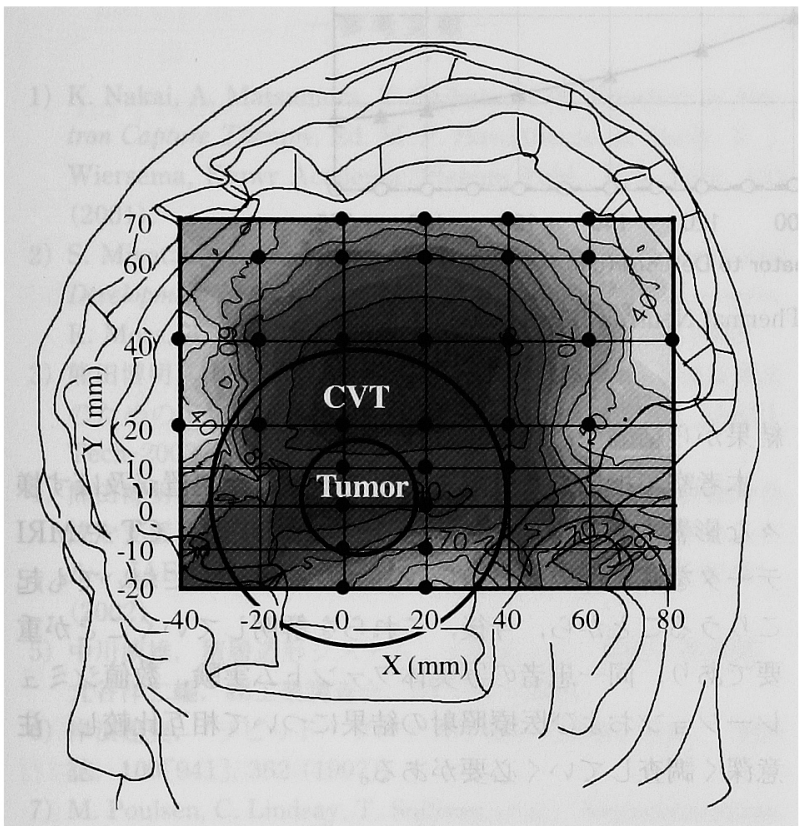

Fig. 5 The measurement result of the thermal neutron flux distribution on the brain surface of the realistic phantom (maximum: $2.17 \times 10^{9} \mathrm{n} / \mathrm{cm}^{2} \cdot \mathrm{s}$ ); CVT: Clinical Target Volume is assumed the $2 \mathrm{~cm}$ area of the tumor outside.

れた熱中性子束を最大值で規格化し，沉用可視化ソフト (Gsharp，KGT 社)を用いて，Fig. 5 のように，2 次元補 間処理した。本処理を行うことにより，側頭葉の部分(画 面中央の部分)に高線量が付与されことが明らかとなっ た。また，腫瘍の中心となる耳の前あたりの部分 (Fig. 5

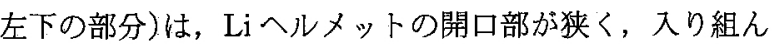
だ構造となっているため，熱中性子束が低くなると思われ たが，挿入したボイドによって，その周辺に比較的高い線 量が付与されていることがわかった。

\section{IV. 考察}

\section{1. 製作誤差に関する考察}

レプリカ製作時の誤差について，1994年，Barker ら ${ }^{13)}$ は頭蓋骨のレプリカを作製し，実際の頭蓋骨と比較し，平 均誤差 $0.47 \mathrm{~mm}$ で再現できると報告している。亦た，

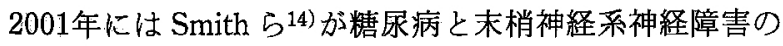
患者の足のレプリカの製作に応用し，実際の足と比較し て, 誤差 $0.3 \mathrm{~mm}$ であったと報告している。本ファントム の誤差は，0.2 mm 以下であり，Barker らや Smith らが
報告している数值より小さかった。

製作の精度を左右するものは，大きく分けてレーザーの 位置決め精度 $(x-y$ 方向) と樹脂の硬化収縮の 2 つが挙げら れる。レーザー制御については近年かなりの改善がみられ， SORIFORM ではほとんど問題にならないレベルにある。 樹脂の硬化収縮については，樹脂の硬化の際に発生する収 縮に起因する内部応力による形状の䄳みが問題となる。こ れは積層・硬化していくために絶えず硬化物には偏りが生 し，造形物の歪みの原因となっている。本ファントムの製 作精度が高いのは，レーザー制御技術進歩もあるが，薄肉 構造にしたため, 硬化收縮による昰む小さく抑えられてい るむのと考えられる。

\section{2. 照射技術に関する誤差要因}

\section{（1）ファントム壁材の水素密度の影響}

TSR-810 壁材 (3 mm)の水素密度比の影響について, 中 性子光子輸送モンテカルロ計算コードである $\mathrm{MCNP}-4 \mathrm{C}$ を用いて評価を行った。3つの材質で造られた円筒水フォ ントム $(\phi 18.6 \mathrm{~cm} \times \mathrm{L} 24 \mathrm{~cm})$ に詨して，熱中性子モード I （直径 $15 \mathrm{~cm}$ のコリメータ）のビームを想定して計算を行 った。(1)成人脳組織(ICRU-4615) $)$ 材質で作成されてい る場合，(2)すべて水の場合，(3)今回のフォントム材である TSR-810 と水を組み合わせた場合の 3 ケースについて評 価した。Table 2 に示すとおり，壁材のファントム表面熱 中性子束に及ぼす影響は小さい。

\section{（2）照射位置の差が及ぼす影響}

ビーム内半径方向の分布抢よびビーム方向の分布を Fig. 6 に示す。これらからわかるように，半径方向の位 置の誤差は大きくなく、コリメータからの距離に対しての ビームの減衰が顕著である。したがって，位置が及ぼす誤 差は $x$ 方向の誤差の影響が大きいと考えられる。ファント 厶の照射位置が $x$ 方向に医療照射時の位置より平均 11 $\mathrm{mm}$ 程度，遠ざかっていることから，照射野に入射した ビーム強度は約 8\%低下するものと考えられる。

\section{3. 脳表面上の位置における熱中性子束を再現でき ない原因}

角度依存性の強い中性子ビームが水素の多い物質に入射 すると，内部で散乱され，方向性を失いながら，スカラ量 である中性子束が増加する現象が観察される。JRR-4の 熱中性子モード I のビームに対する円筒水ファントムの実 


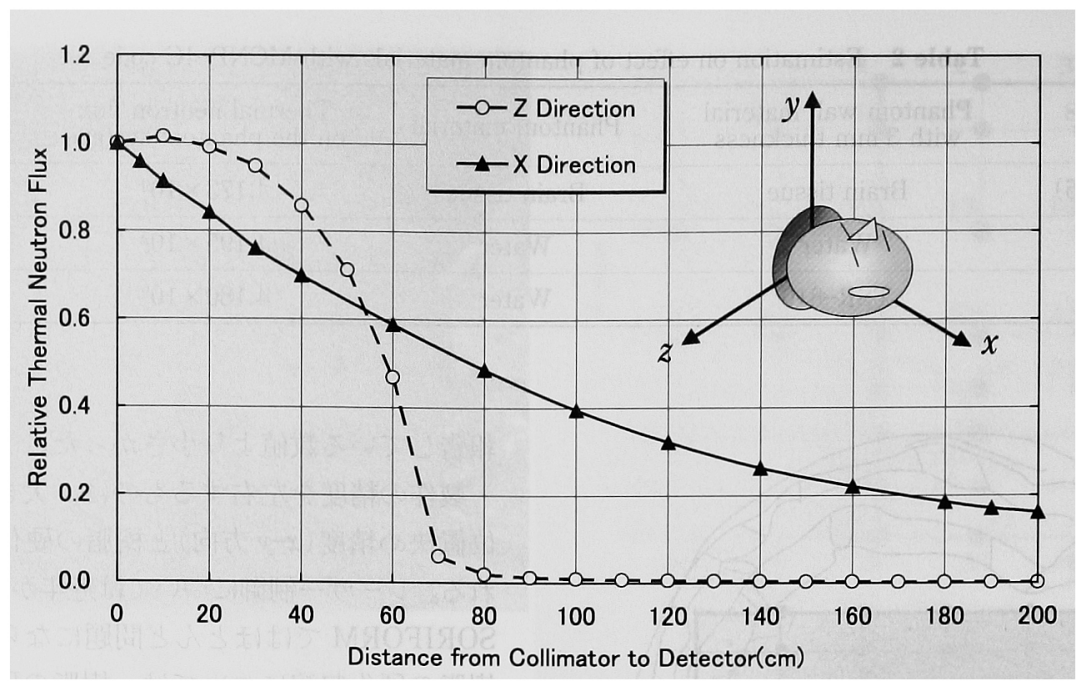

Fig. 6 The beam profile with the Thermal Neutron Beam mode I

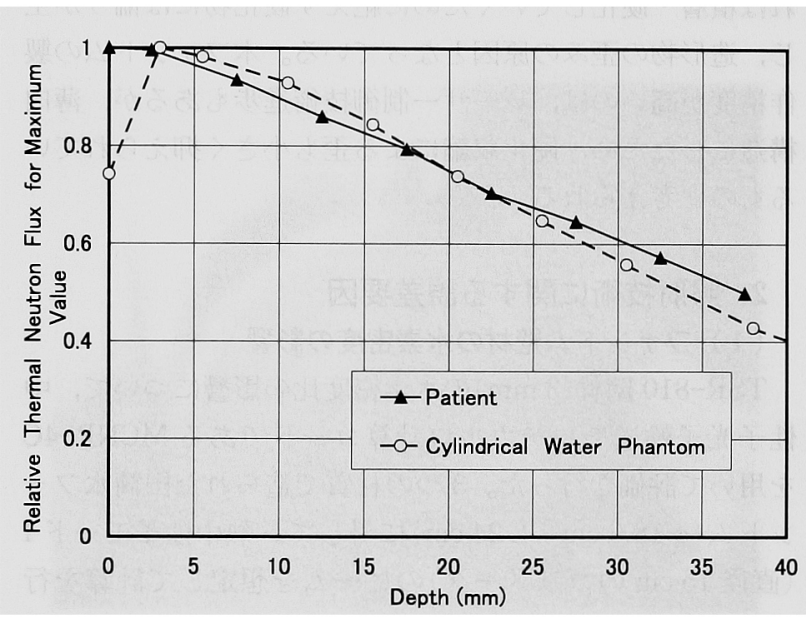

Fig. 7 The thermal neutron flux profile in a cylindrical water phantom (size $\phi 18.6 \mathrm{~cm} \times \mathrm{L} 24 \mathrm{~cm}$ ) for the Thermal Neutron Beam mode I with $\phi 15 \mathrm{~cm}$ collimator

験に打いて観察される深部方向の分布 ${ }^{16) を ~ F i g . ~} 7$ に示 す。ファントム内の熱中性子ピークはファントム表面に対 して約1.3倍になる。しかし，医療照射で観察された患者 の深さ方向の分布では，ピークが観察されていないことか ら, 脳を保護するために用いられる薄い人工膜(ドレープ) と脳表面との間に液層が存在していて, その液層の中で, すでにピークに到達してしまい, 円筒水ファントムの実験 で観測されるピークより深いところで見られる減衰部分に 相当する部分のみを計測していたと考えられる。つまり， 脳表面一ドレープ間に存在したと見られる液層(数 $\mathrm{mm}$ )の 間に熱中性子束のピークが存在し，医潦照射で観察された 最大值はピーク近傍の值(表面より $22 \%$ 高い)を観察した と解积すべきである。ただし，医療照射で得られるデータ 数が限られていること，対象とした患者の脳に配置した金 線の正確な位置がわからないこと, ビーム強度の再現性, ボイド形状の再現性など不明確な点も多く, 限られた実験
結果から結論づけることは難しい。

本考察で指摘した医療上現場で施された処置が及ほす様 々な影響を再現できない原因について，同じ CT や MRI データを基に作成した数值シミュレーションに执てを起 こりうることから，今後，これらを解明していくことが重 要であり, 同一患者の写実体ファントム実験, 数值シミュ レーションおよび医療照射の結果について相互比較し，注 意深く調査していく必要がある。

\section{V. 結 語}

本研究では，医療照射実施患者の頭部モデルフォントム を製作し，これを用いて実際の医療照射条件の再現を試み た。脳表面の熱中性子分布について実際の医療照射時に得 られたデータと比較することにより，その再現性について 検討した。

最先端の光造形技術を応用して，臨床照射例（1 例）をモ デルに頭部モデルファントムの製作を行い，CT データの 変換, 輪郭抽出, 面張り等の手順から製作までの一連の技 術を確保することができた。本フォントムは薄肉構造を採 用したことにより，歪による誤差を $0.2 \mathrm{~mm}$ に抑えること ができた。製作上の課題として，(1)使用した樹脂の水素密 度が生体組織より約 $30 \%$ 低いため，中性子用のファント ム材に適切な材料開発が必要であること，(2)耳の周りなぞ の複雑な部分にバッドエッジが発生しやすいことなどがわ かった。

製作した本ファントムを用いて医療照射条件を再現した 結果，医療照射時に脳に刺し込んだ金線の脳表面上の位固 における熱中性子束の值と比較して，本ファントム実験で 得られた值は約 $22 \%$ 低い值を示していることがわかっ た。この原因としてドレープと脳表面に溜まる液層の存在 が考えられる。

今後の課題として, 脳表面に溜まる液層の存在や，これ が及ぼす影響を定量的に評価した上で，光造形用データ変 
換工程の効率改善を行い,さらにファントム内部の線量分 布の 3 次元測定法の開発を進めていく。本報で指摘した 製作上の課題の解決と液層の存在の再現が可能となれば, 写実体ファントムを用いた評価方法は, 複雑形状をした部 位に対する中性子挙動を忠実に再現できることから，これ らを計算する線量評価システム等の检証に有効な手法とな るものと期待される。

\section{一参考文献一}

1) K. Nakai, A. Matsumura, Y. Shibata, et al., Frontiers in Neutron Capture Therapy, Ed. M. F. Hawathorne, K Shelly, R. J. Wiersema, Kluwr Academic/Plebum Publ., New York, 133 (2001).

2) S. Miyatake, K. Kajimoto, S. Kawabata, et al., Research and Development in Neutron Capture Therapy, Ed. W. Sauerwein, R. Moss, A. Wittig, Monduzzi Editore, Italy, 1129 (2002).

3）熊田博明, 山本和喜, 鳥居義也, 他, 木ウ素中性子捕捉療法 のための BNCT 線量評価システム(JCDS)の開発, JAERITech-2003-002, 日本原子力研究所, (2003).

4）熊田博明, 鳥居義也, ホウ素中性子捕捉療法の治療計画の作 成を支援する線量評価システム：JCDS ユーザーズマニュア ル, JAERI-Data / Code 2002-018, 日本原子力研究所, (2002).

5）中川威雄, 積層造形システム; 三次元コピー技術の新展開, 丸谷洋二編, 工業調查会, 65 94 (1996).

6）岸浪建史, “ラピッド・プロトタイピング技術の展望,”機械 誌, 100[941], 362 (1997).

7) M. Poulsen, C. Lindsay, T. Sullivan, et al., "Stereolithographic modelling as an aid to orbital brachytherapy," Int. J. Radiat.
Oncol. Biol. Phys., 44[3], 731 (1999).

8) T. Sakae, A. Nohtomi, A. Maruhashi, et al., "Multi-layer energy filter for realizing conformal irradiation in charged particle therapy," Med. Phys., 27[2], 368 (2000).

9）山本哲哉, 山本和喜, 松村 明, 他, JRR-4 熱外中性子ビ一 么の in vitro 生物学的效果一フリービーム条件ならびにファ ントム条件での測定, JAERI-Research 2002-011，日本原子 力研究所, (2002).

10) H. Hatanaka, Y. Urano, "Eighteen autopsy cases of malignant brain tumors treated by boron-neutron capture therapy between 1968 and 1985," Boron-Neutron Capture Therapy for Tumors, ed. H. Hatanaka, Nishimura Co. Ltd., Niigata, 381 (1986).

11）熊田博明, 松村 明, 中川義信, “原子炬による医療照射のた めの患者セッティングシステムの開発, ”原子力和文論文誌, $1[1], 59$ (2002).

12）横尾健司, 鳥居義也, 鯉㴊 犦, 他, “医療照射における熱中 性子束測定技術,”JAERI-M 94-058, 日本原子力研究所, (1994).

13) T. M. Barker, W. J. Earwaker, D. A. Lisle, "Accuracy of stereolithographic models of human anatomy," Australas. Radiol., 38[2], 106 (1994).

14) K. E. Smith, P. K. Commean, D. D. Robertson, et al., "Precision and accuracy of computed tomography foot measurements," Arch. Phys. Med. Rehabil., 82[7], 925 (2001).

15) Photon, Electron, Proton and Neutron Interaction Data for Body Tissues," ICRU Report 46, p. 13 (1992).

16）山本和喜, 熊田博明, 鳥居義也, 他, “ファントム内の 2 次 元熱中性子束の分布測定之線量分布特性評価, " JAERI-Tech2001-015, 日本原子力研究所, (2001). 